\title{
Physiologic characteristics of corn and Urochloa brizantha (Hochst. ex A. Rich.) R.D. Webster in intercropping cultivation
}

\author{
Orismário L. Rodrigues ${ }^{1}$, João Carlos C. Galvão ${ }^{2}$, Evander A. Ferreira ${ }^{3}$, Daniel V. Silva ${ }^{1^{*}}$, \\ Márcia V. Santos ${ }^{3}$, Lino R. Ferreira ${ }^{2}$, Rosana C. Pereira ${ }^{3}$, and Rafael S. Felipe ${ }^{2}$
}

Competition between weeds and crops results in a lower availability of some resources to crop species, which causes deficiencies, such as water and nutritional deficiencies and low light quality or quantity. The aims of this study were to evaluate the effects of Urochloa brizantha (Hochst. ex A. Rich.) R.D. Webster, cv. Xaraés (brachiaria) emergence times comparing with corn (Zea mays L.), in addition to the fertilization and application of different nicosulfuron and atrazine herbicides levels, on the physiological characteristics of intercropped species. The physiological characteristics Brachiaria plants that were treated with herbicides were negatively affected. The emergence time of Brachiaria plants in comparison with corn altered the physiological characteristics of both. The Brachiaria plants that emerged before corn presented higher photosynthetic and transpiration rates and reduced the intensity of these characteristics in corn. Thus, the Brachiaria plants that emerged before the corn crop presented a higher physiological efficiency, and they were more competitive than the weeds that emerged during other seasons.

Key words: Atrazine, competition, fertilizing, intercropping, nicosulfuron, Zea mays.

\section{INTRODUCTION}

Plant competition is one of the primary biotic limiting factors in corn (Zea mays L.) crop yield, and it leads to high yield losses in some cases. Several weed species can infest corn crops, Brachiaria among them (Silva et al., 2007). Brachiaria plants belong to the corn family (Poaceae), and for that reason, they have similar demands for environment resources, which can interfere in the development of the agricultural crop (Radosevich et al., 1997).

Among the resources for which plants compete, water is considered to be one of the most limiting to production, primarily during hot and low rainfall seasons. Under these conditions, an important characteristic of cultivated plants can be affected, namely the water use efficiency

${ }^{1}$ Faculdade Univértix, Departamento de Agronomia, Rua Bernardo Torres 180, Bairro do Retiro, Matipó, Minas Gerais, Brasil. *Corresponding author (danielvaladaos@yahoo.com.br).

${ }^{2}$ Universidade Federal de Viçosa, Departamento de Fitotecnia, Avenida P.H. Rolfs, Campus Universitário, Minas Gerais 36571000, Viçosa, Brasil.

${ }^{3}$ Universidade Federal dos Vales do Jequitinhonha e Mucuri, Rua da Glória 187, Centro-CEP 39100-000, Minas Gerais, Diamantina, Brasil.

Received: 16 October 2013.

Accepted: 17 April 2014.

doi:10.4067/S0718-58392014000300002
(WUE). The WUE is defined as the amount of water that is transpired by a plant to produce a certain amount of DM (Silva et al., 2007).

The competitive potential of plants for environmental resources varies according to the species present in an area (Rigoli et al., 2008), the population level (Vidal et al., 2004), the time of emergence of grass forage in relation to the crop (Silva et al., 2007), and the competitive characteristics of the cultivars (Galon et al., 2007). Competition between weed plants and crops leads to a lower supply of some resources to both species, causing deficiencies that culminate in alterations to the physiological characteristics associated with photosynthesis, such as water (Floss, 2008) and nutritional (Melo et al., 2006) deficiencies, and low light quality or quantity (Sharkey and Raschke, 1981). These limitations may lead to alterations in stomatal conductance, internal gas concentration and, consequently, in the photosynthetic activity and WUE. The most efficient water use is directly associated with the stomatal opening time; as carbon dioxide $\left(\mathrm{CO}_{2}\right)$ penetrates the leaf, water is lost by transpiration with variable intensity, depending on the potential gradient between the leaf surface and the atmosphere (Concenço et al., 2007; 2009).

Corn is considered to be a strong competitor with small plants, such as Brachiaria, primarily because of their size advantage over forage plants, as evidenced by the higher DM accumulation rate produced during their initial 
development stages (Silva et al., 2007). Corn presents an elevated interception capacity for photosynthetically active radiation along its canopy, reducing the quantity of this resource to other species. This interception varies according to the morphological characteristics of the cultivar, such as the plant height and leaf formation, in addition to the selected population (Freitas et al., 2008), crop development and interference from other species. However, studies reporting on physiological alterations in intercropped plants are scarce.

Thus, this study aimed to evaluate the effects of the Brachiaria emergence time in relation to that of corn, in addition to the effects of fertilization and nicosulfuron and atrazine herbicides on the physiological characteristics of corn and Brachiaria brizantha (Hochst. ex A. Rich.) Stapf, cv. Xaraés in intercropped cultivation.

\section{MATERIALS AND METHODS}

This study was conducted in a greenhouse at the Federal University of Viçosa (UFV, Viçosa, Minas Gerais) in a randomized complete block design, with four replicates in a $(2 \times 2 \times 3)$ factorial scheme as follows: a) with and without herbicides; b) total fertilization and $100 \%$ recommended fertilization for pot cultivation; and c) three emergence seasons of Urochloa brizantha 'Xaraés' (Brachiaria) in comparison with corn. During season 1, Brachiaria emerged $10 \mathrm{~d}$ before corn; during season 2, Brachiaria and corn emerged at the same time; and during season 3, Brachiaria emerged $10 \mathrm{~d}$ after corn.

The experimental units were constituted of punched bottom pots containing $20 \mathrm{dm}^{3}$ substrate (soil + fertilizers). A red-yellow Latosol was used as the substrate, and it had been previously corrected and fertilized with $20 \mathrm{~g}$ sodium chloride, $500 \mathrm{~g}$ simple superphosphate, $50 \mathrm{~g}$ ammonium sulfate, and $150 \mathrm{~g}$ dolomitic limestone, as recommended by Cantarutti et al. (2007) for pot fertilization.

According to the analysis, the soil presented the following characteristics: $\mathrm{pH}$ in water 4.3 , organic matter: $2.5 \%, 1.5 \mathrm{mg} \mathrm{P} \mathrm{dm}^{-3}, 40 \mathrm{mg} \mathrm{K} \mathrm{dm}^{-3}, 0.5 \mathrm{cmol}_{\mathrm{c}} \mathrm{Al}^{3+} \mathrm{dm}^{-3}$, $1.3 \mathrm{cmol}_{\mathrm{c}} \mathrm{Ca}^{2+} \mathrm{dm}^{-3}, 0.2 \mathrm{cmol}_{\mathrm{c}} \mathrm{Mg}^{2+} \mathrm{dm}^{-3}$, cation exchange capacity effective $(\mathrm{CTCt})=2.1 \mathrm{cmol}_{\mathrm{c}} \mathrm{dm}^{-3}, \mathrm{CTC}=6.39$ $\mathrm{cmol}_{\mathrm{c}} \mathrm{dm}^{-3}, \mathrm{H}+\mathrm{Al}=4.79 \mathrm{cmol}_{\mathrm{c}} \mathrm{dm}^{-3}$, base saturation $=1.6$ $\mathrm{cmol}_{\mathrm{c}} \mathrm{dm}^{-3}, \mathrm{Al}$ saturation $=25 \%$, and $38 \%$ clay .

After filling pots with substrate, two corn seeds and six Brachiaria seeds were sowed per pot, and resulting seedlings were subsequently thinned to one corn and three Brachiaria plants. The pots were maintained in a protected environment inside a greenhouse. Irrigation was performed daily to maintain the soil at approximately $80 \%$ field capacity. Preliminary germination tests were performed for different forage emergence times in relation to corn. The tests uncovered an interval of $10 \mathrm{~d}$ between sowing and Brachiaria emergence and $5 \mathrm{~d}$ for corn emergence. To following different Brachiaria germination times in relation to corn were identified: 1) Brachiaria emergence
$10 \mathrm{~d}$ before corn $=$ corn sowing $5 \mathrm{~d}$ after Brachiaria emergence; 2) Brachiaria emergence at the same time as corn = corn sowing $5 \mathrm{~d}$ after Brachiaria sowing; and 3) Brachiaria emergence $10 \mathrm{~d}$ after corn = Brachiaria sowing on the day of corn emergence. The application of the herbicides atrazine (Atrazinex, 6-chloro-N2-ethylN4-isopropyl-1,3,5-triazine-2,4-diamine at $4 \mathrm{~L} \mathrm{ha}^{-1}$ ) and nicosulfuron (Sanson, 2-[(4,6-dimethoxypyrimidin-2yl carbamoyl) sulfamoyl]-N,N-dimethylnicotinamide $150 \mathrm{~mL} \mathrm{ha}^{-1}$ ) was performed $21 \mathrm{~d}$ after corn emergence when crop plants presented four completely expanded leaves. For the herbicide applications, a coastal pulverizer

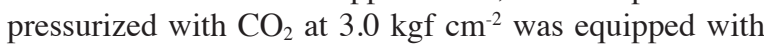
a bar and a pulverization tip (TT 110.02 series) and calibrated to apply $200 \mathrm{~L} \mathrm{ha}^{-1}$ herbicide syrup.

The physiological evaluations were performed during the middle third of the first completely expanded leaf of the Brachiaria primary tillage and in the first completely expanded corn leaf at 15 and $45 \mathrm{~d}$ after herbicide application. An infrared gas analyzer was used (IRGA LCA Pro ${ }^{+}$, ADC BioScientific, Hoddesdon, UK) for these evaluations in an open greenhouse, allowing for free air circulation. The stomatal conductance to water vapor

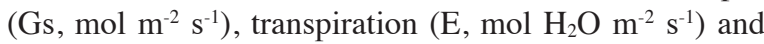
photosynthetic $\left(\mathrm{A}, \mu \mathrm{mol} \mathrm{m} \mathrm{m}^{-2} \mathrm{~s}^{-1}\right)$ rates were evaluated. In addition, the water use efficiency (WUE, mol CO $\mathrm{mol}^{-1}$ $\mathrm{H}_{2} \mathrm{O}$ ) was obtained by studying the relation between the $\mathrm{CO}_{2}$ concentration that was fixed by photosynthesis and the transpired water during the same period, in addition to the internal C/atmospheric $\mathrm{C}$ ratio (Ic/Ac). Evaluations were performed between 07:00 and 10:00 h.

Data were subjected to ANOVA and the means were compared by Tukey's test at $5 \%$ probability.

\section{RESULTS AND DISCUSSION}

At $15 \mathrm{~d}$ after herbicide application, the Brachiaria plants that were treated with a nicosulfuron and atrazine mixture presented a lower transpiration rate $(\mathrm{E})$ when compared with treatments without the mixture (Table 1). Nicosulfuron is an inhibitor of the acetolactate synthase enzyme (ALS), which is responsible for the synthesis of branched amino acids (leucine, isoleucine, and valine), and atrazine is responsible for inhibiting photosystem II, which paralyzes the flow of electrons in the chloroplast

Table 1. Photosynthetic activity $\left(\mathrm{A}, \mathrm{mol} \mathrm{m} \mathrm{m}^{-2} \mathrm{~s}^{-1}\right)$, transpiration $(\mathrm{E}$,

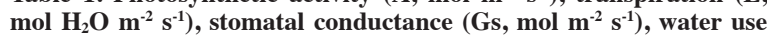
efficiency (WUE, mol CO $\mathrm{Col}^{-1} \mathrm{H}_{2} \mathrm{O}$ ) and the internal and external $\mathrm{CO}_{2}$ concentration ratio (Ic/Ac) in Brachiaria plants as evaluated 15 d after atrazine + nicosulfuron herbicide applications.

\begin{tabular}{lccccc}
\hline Herbicide & A & E & Gs & WUE & Ic/Ac \\
\hline With herbicides & $8.20 \mathrm{~b}$ & $3.02 \mathrm{~b}$ & $0.16 \mathrm{~b}$ & $2.70 \mathrm{~b}$ & $0.57 \mathrm{a}$ \\
Without herbicides & $23.10 \mathrm{a}$ & $4.36 \mathrm{a}$ & $0.25 \mathrm{a}$ & $5.30 \mathrm{a}$ & $0.54 \mathrm{~b}$ \\
CV, \% & 26.32 & 22.33 & 41.55 & 23.40 & 11.04 \\
\hline
\end{tabular}

Means followed by same letter in the column do not differ according to the $\mathrm{F}$ test at $5 \%$ probability. 
transport chain. Thus, it is believed that these herbicides interfere in $\mathrm{E}$, given that atrazine acts directly and nicosulfuron interferes indirectly in the photosynthetic apparatus.

Reductions in the transpiration rate are associated with stomatal closure, and variations in stomatal opening cause alterations in the water potential (Brodribb and Hill, 2000). A plant tends to close its stomata when light levels are below photosynthetically active radiation, or to avoid water stress (Cochard et al., 2002). All these parameters are connected by a cost/benefit relation because $\mathrm{E}$ is also a leaf temperature reduction mechanism. Transpiration and $\mathrm{CO}_{2}$ uptake processes only occur when the stomata are open, in addition to stomatal conductance (Gs). Because of the latent heat of evaporation (heat is effectively used to "heat" water and allow evaporation), transpiration has a powerful cooling effect, which is important for leaf temperature regulation (Farquhar and Raschke, 1978).

The presence of herbicides reduced the Gs of Brachiaria plants (Table 1). This finding is also possibly explained by stomatal closure, which is influenced by several factors, such as the water availability, light and energy, and pollution and herbicides used for weed control.

A reduction in the stomatal conductance was observed in soybean (Glycine max [L.] Merr.) and portulaca-weed (Portulaca oleracea L.) $6 \mathrm{~h}$ after applying lactofen, which is a protox enzyme inhibitor (Wichert and Talbert, 1993). Foliar conductance is partially composed of epidermis cuticle conductance and, when stomata are open, by Gs as controlled by guard cells in the stomata. Thus, Gs is proportional to the stomata number, size, and opening diameter; these characteristics depend on other endogenous and environmental factors in addition to the previously mentioned factors (Brodribb and Holbrook, 2003). Brachiaria plantlets are mostly considered to be sensitive to nicosulfuron applications that are performed during early post-emergence in recommended commercial doses, and the symptoms of sensitive plants are foliar chlorosis, necrosis, and growth reduction (Lorenzi, 2000; Shim et al., 2003).

Brachiaria plants submitted to herbicide mixtures presented a lower photosynthetic rate (A) than those that did not receive herbicide treatment (Table 1). This reduction can be explained by the interference of herbicides in the plant photosynthetic apparatus. The higher Ic/Ac ratio in herbicide-treated plants indicates that plants fixed low $\mathrm{CO}_{2}$ concentrations in the substomatal chamber, showing that photosynthesis reduction is a result of damages during the photosynthetic process (Table 1). Ogliari et al. (2009) noticed that the mesotrione herbicide reduced the photosynthetic rate in corn plants by $78 \%$ on the first, $66 \%$ on the second, and $75 \%$ on the third day after application relative to the control.

When comparing times of emergence, Brachiaria plants that emerged $10 \mathrm{~d}$ before corn exhibited a higher
E than the Brachiaria from treatments with simultaneous and subsequent emergence relative to corn (Table 2). Plants that emerged $10 \mathrm{~d}$ after corn presented three leaves during this phase, were younger and, consequently, more sensitive to herbicide action, in addition to engaging in less competition with the crop. However, if Brachiaria is not correctly managed, corn production will be compromised and it will not be possible to remove the weeds without causing severe damage to the agricultural crop. The alternative is to apply sub-doses of nicosulfuron to delay Brachiaria growth without damaging the corn too much. The dosage depends on the Brachiaria growth stage and on weeds that occur in the area. The more developed the Brachiaria, the higher the recommended dosage (Ferreira et al., 2007).

In comparing treatments with and without herbicides within each Brachiaria emergence time, it was clear that the treatments with herbicide applications presented a lower $\mathrm{A}$ at all emergence times at $45 \mathrm{~d}$ after application (Table 3), demonstrating that herbicide applications promote a reduction in the A of Brachiaria, regardless of the weed's developmental stage. However, herbicide applications promoted a higher photosynthesis reduction when Brachiaria plants emerged at the same time or after corn plants (Table 3), confirming the higher efficiency of herbicide application in younger plants.

Regarding the fertilizer levels within specific time periods, the photosynthesis was inferior in the treatment receiving half the fertilizer at $10 \mathrm{~d}$ after emergence

Table 2. Photosynthetic activity $\left(\mathrm{A}, \mathrm{mol} \mathrm{m} \mathrm{m}^{-2} \mathrm{~s}^{-1}\right)$, transpiration (E, mol $\left.\mathrm{H}_{2} \mathrm{O} \mathrm{m}^{-2} \mathrm{~s}^{-1}\right)$, stomatal conductance $\left(\mathrm{Gs}\right.$, mol m $\left.\mathrm{m}^{-2} \mathrm{~s}^{-1}\right)$, water use efficiency (WUE, mol $\mathrm{CO}_{2} \mathrm{~mol}^{-1} \mathrm{H}_{2} \mathrm{O}$ ) and the internal and external $\mathrm{CO}_{2}$ concentration ratio (Ic/Ac) of Brachiaria plants according to the emergence time on different days at $\mathbf{4 5} \mathbf{d}$ after applying atrazine + nicosulfuron herbicides.

\begin{tabular}{lccccc}
\hline $\begin{array}{l}\text { Brachiaria } \\
\text { emergence }\end{array}$ & $\mathrm{A}$ & $\mathrm{E}$ & Gs & WUE & Ic/Ac \\
\hline $10 \mathrm{DBE}$ & $21.62 \mathrm{a}$ & $4.12 \mathrm{a}$ & $0.24 \mathrm{~ns}$ & $5.20 \mathrm{a}$ & $0.57 \mathrm{a}$ \\
Concomitant & $13.20 \mathrm{~b}$ & $3.25 \mathrm{~b}$ & 0.25 & $2.96 \mathrm{~b}$ & $0.59 \mathrm{a}$ \\
$10 \mathrm{DAE}$ & $15.92 \mathrm{~b}$ & $3.69 \mathrm{ab}$ & 0.24 & $3.57 \mathrm{~b}$ & $0.50 \mathrm{~b}$ \\
$\mathrm{CV}, \%$ & 26.33 & 22.12 & 41.98 & 23.76 & 11.08 \\
\hline
\end{tabular}

Means followed by same letter in the column do not differ according to Tukey's test at $5 \%$ probability.

DBE: Days before corn emergence, DAE: days after corn emergence, ns: nonsignificant.

Table 3. The photosynthetic activity (A) of Brachiaria plants according to their emergence times relative to corn emergence, herbicide application and fertilization levels at $45 \mathrm{~d}$ after herbicide application.

\begin{tabular}{lcccc}
\hline $\begin{array}{l}\text { Brachiaria } \\
\text { emergence }\end{array}$ & $\begin{array}{c}\text { Total } \\
\text { fertilizer }\end{array}$ & $\begin{array}{c}\text { Half } \\
\text { fertilizer }\end{array}$ & $\begin{array}{c}\text { With } \\
\text { herbicide }\end{array}$ & $\begin{array}{c}\text { Without } \\
\text { herbicide }\end{array}$ \\
\hline & \multicolumn{5}{c}{$\mathrm{mol} \mathrm{m}^{-2} \mathrm{~s}^{-1}$} \\
$10 \mathrm{DBE}$ & $24.5 \mathrm{aA}$ & $18.71 \mathrm{~b}$ & $16.52 \mathrm{bA}$ & $26.83 \mathrm{aA}$ \\
Concomitant & $12.9 \mathrm{aB}$ & $13.62 \mathrm{a}$ & $5.52 \mathrm{bB}$ & $20.94 \mathrm{aA}$ \\
$10 \mathrm{DAE}$ & $12.4 \mathrm{bB}$ & $19.54 \mathrm{a}$ & $3.99 \mathrm{bB}$ & $27.91 \mathrm{aA}$ \\
$\mathrm{CV}, \%$ & & & 26.13 & \\
\hline
\end{tabular}

Means followed by the same lower-case letter in the lines and capital letters in the columns do not differ according to Tukey's test at $5 \%$ probability. DBE: Days before corn emergence, DAE: days after corn emergence. 
(DAE). This reduction may have been caused by a nutritional limitation. For Brachiaria plants that received the full dose of fertilizer, a lower A was observed when plants emerged $10 \mathrm{~d}$ after corn (Table 3 ). This reduction may have been caused by higher initial corn development, which was caused by previous emergence and greater nutrient availability.

The competition between weeds and crops is a critical factor for crop development when weed species sets at the same time or before the crop (Radosevich et al., 1997). However, if the crop is established first, it will be able to cover the soil quickly because of its cultivated species, energy, initial growth rate and seedling density, which will exclude or significantly inhibit the growth of weeds. Herbicide application in addition to Brachiaria emergence at the same time or after corn provide a photosynthetic rate reduction in forage, interfering in the competitive capacity of Brachiaria (Table 3).

The difference among fertilization levels within treatments with and without herbicides and for times within herbicide treatments was verified between levels within treatments. In Table 3, the competition factor is included because Brachiaria plants that emerged before corn presented a higher competitive capacity, which must be taken into consideration. However, the E was not affected under any fertilization level among treatments with and without herbicides. No differences were observed in the transpiration and WUE of Brachiaria plants intercropped with corn, for fertilization levels within treatments with and without herbicides and for emergence times within herbicide treatments (Table 4).

Regarding treatments with and without herbicides within each time period, there was no difference in the $\mathrm{E}$ and WUE between treated or untreated plants and those that emerged before corn. However, for plants that emerged simultaneously and after corn, the samples treated with herbicides presented lower $\mathrm{E}$ and WUE values (Table 4). For times within treatments that were with and without herbicide, plants that emerged $10 \mathrm{~d}$ before corn in the presence of herbicide exhibited lower $\mathrm{E}$ and WUE values in comparison with those that emerged simultaneously and after corn. No difference was noted

Table 4. The transpiration and water use efficiency of Brachiaria plants intercropped with corn according to emergence times when comparing corn emergence and herbicide application at $55 \mathrm{~d}$ after herbicide application.

\begin{tabular}{|c|c|c|c|c|}
\hline \multirow[b]{2}{*}{$\begin{array}{l}\text { Brachiaria } \\
\text { emergence time }\end{array}$} & \multicolumn{2}{|c|}{ Transpiration } & \multicolumn{2}{|c|}{ Water use efficiency } \\
\hline & $\begin{array}{c}\text { With } \\
\text { herbicide }\end{array}$ & $\begin{array}{c}\text { Without } \\
\text { herbicide }\end{array}$ & $\begin{array}{c}\text { With } \\
\text { herbicide }\end{array}$ & $\begin{array}{l}\text { Without } \\
\text { herbicide }\end{array}$ \\
\hline & \multicolumn{2}{|c|}{$\mathrm{mol} \mathrm{H}_{2} \mathrm{O} \mathrm{m}^{-2} \mathrm{~s}^{-1}$} & \multicolumn{2}{|c|}{$\mathrm{mol} \mathrm{CO} \mathrm{mol}^{-1} \mathrm{H}_{2} \mathrm{O}$} \\
\hline $10 \mathrm{DBE}$ & $3.74 \mathrm{aA}$ & $4.50 \mathrm{aA}$ & $4.97 \mathrm{aA}$ & $5.44 \mathrm{aA}$ \\
\hline Concomitant & $2.07 \mathrm{bA}$ & $4.44 \mathrm{aA}$ & $1.85 \mathrm{bA}$ & $4.08 \mathrm{aA}$ \\
\hline $10 \mathrm{DAE}$ & $3.24 \mathrm{bA}$ & $4.14 \mathrm{aA}$ & $1.60 \mathrm{bA}$ & $5.56 \mathrm{aA}$ \\
\hline $\mathrm{CV}, \%$ & \multicolumn{2}{|c|}{20.5} & \multicolumn{2}{|c|}{23.0} \\
\hline
\end{tabular}

Means followed by same lower-case letter in line and capital letter in column do not differ according to Tukey's test at $5 \%$ probability.

DBE: Days before corn emergence, DAE: days after corn emergence. between the emergence times of plants that did not receive herbicides applications (Table 4). When comparing the $\mathrm{E}$ and WUE in the presence and absence of herbicides between the different times of emergence, the treatments that received products presented lower E and WUE values when Brachiaria germinated simultaneously with corn or $10 \mathrm{~d}$ afterwards, indicating higher herbicide efficiency when applied to younger plants (Table 4).

Unlike Brachiaria plants that were treated with atrazine and nicosulfuron herbicides in sub-doses, the corn plants presented higher photosynthesis, E, stomatal conductance, and WUE values (Table 5). The improved physiological efficiency of corn plants is explained by the Brachiaria growth rate reduction caused by herbicide application, because the lower growth of Brachiaria plants reduces competition with corn plants for nutrients, primarily for water. The low photosynthetic rate presented by corn plants in the treatments without herbicide applications (Table 5) was most likely caused by a water deficit produced by competition with Brachiaria plants. The most significant plant response to water deficits consists of stomatal closure (Taiz and Zeiger, 2009). Plants frequently show physiological responses when exposed to water deficit situations, which results directly in water savings. Thus, stomatal conductance is directly associated with water availability in the soil (Bianchi et al., 2007). When evaluating the Ic/Ac ratio, the lower value was verified in treatments without herbicide application (Table 5). This finding indicates that the photosynthetic apparatus is working normally and that the E reduction is associated with a reduced $\mathrm{CO}_{2}$ concentration in the substomatal chamber, which is caused by stomatal closure. The plants in treatments with herbicide applications presented higher stomatal conductance, which allows for higher $\mathrm{CO}_{2}$ synthesis and increases the photosynthetic rate. This finding is evidenced by the higher Ic/Ac ratio, indicating that there is an appropriate $\mathrm{CO}_{2}$ supply for the cells.

With regards to the Brachiaria emergence time, the corn plants presented lower E, A, stomatal conductance, and WUE in earlier Brachiaria emergence treatments (Table 6). The photosynthesis reduction in corn plants caused by early Brachiaria emergence is also associated with the competition process between plants and not to the direct interference of herbicides in the photosynthesis phases. Brachiaria plants that emerged before corn

Table 5. Photosynthetic activity $\left(\mathrm{A}, \mathrm{mol} \mathrm{m} \mathrm{m}^{-2} \mathrm{~s}^{-1}\right)$, transpiration $(\mathrm{E}$, mol $\left.\mathrm{H}_{2} \mathrm{O} \mathrm{m} \mathrm{m}^{-2} \mathrm{~s}^{-1}\right)$, stomatal conductance $\left(\mathrm{Gs}\right.$, mol m $\left.\mathrm{m}^{-2} \mathrm{~s}^{-1}\right)$, water use efficiency (WUE, mol CO $\mathrm{Col}^{-1} \mathrm{H}_{2} \mathrm{O}$ ) and the internal and external $\mathrm{CO}_{2}$ concentration ratio (Ic/Ac) in corn plants as evaluated $15 \mathrm{~d}$ after atrazine + nicosulfuron herbicide application.

\begin{tabular}{llcrrr}
\hline Herbicide & A & E & Gs & WUE & Ic/Ac \\
\hline With herbicide & $52 \mathrm{a}$ & $1.40 \mathrm{a}$ & $7.3 \mathrm{a}$ & $7.0 \mathrm{a}$ & $0.426 \mathrm{a}$ \\
Without herbicide & $41 \mathrm{~b}$ & $0.82 \mathrm{~b}$ & $6.7 \mathrm{~b}$ & $5.9 \mathrm{~b}$ & $0.330 \mathrm{~b}$ \\
$\mathrm{CV}, \%$ & 22.03 & 14.58 & 28.23 & 16.90 & 13.02 \\
\hline
\end{tabular}

Means followed by same letter in column do not differ according to $\mathrm{F}$ test at $5 \%$ probability. 
Table 6. Photosynthetic activity $\left(\mathrm{A}, \mathrm{mol} \mathrm{m}^{-2} \mathrm{~s}^{-1}\right)$, transpiration (E, mol $\mathrm{H}_{2} \mathrm{O} \mathrm{m}^{-2} \mathrm{~s}^{-1}$ ), stomatal conductance (Gs, mol m ${ }^{-2} \mathrm{~s}^{-1}$ ), water use efficiency (WUE, mol $\mathrm{CO}_{2} \mathrm{~mol}^{-1} \mathrm{H}_{2} \mathrm{O}$ ) and the internal and external $\mathrm{CO}_{2}$ concentration ratio (Ic/Ac) in corn plants according to Brachiaria emergence times as evaluated $45 \mathrm{~d}$ after atrazine + nicosulfuron herbicide application.

\begin{tabular}{lccccc}
\hline $\begin{array}{l}\text { Brachiaria } \\
\text { emergence }\end{array}$ & $\mathrm{A}$ & $\mathrm{E}$ & Gs & WUE & Ic/Ac \\
\hline $10 \mathrm{DBE}$ & $36.12 \mathrm{~b}$ & $6.03 \mathrm{~b}$ & $0.51 \mathrm{~b}$ & $5.97 \mathrm{~b}$ & $0.290 \mathrm{~b}$ \\
Concomitant & $54.81 \mathrm{a}$ & $7.41 \mathrm{a}$ & $1.36 \mathrm{a}$ & $7.03 \mathrm{a}$ & $0.437 \mathrm{a}$ \\
$10 \mathrm{DAE}$ & $52.97 \mathrm{a}$ & $7.69 \mathrm{a}$ & $1.50 \mathrm{a}$ & $6.97 \mathrm{a}$ & $0.419 \mathrm{a}$ \\
CV $\%$ & 22.03 & 14.58 & 28.23 & 16.90 & 13.02 \\
\hline
\end{tabular}

Means followed by same letter in column do not differ according to Tukey's test at $5 \%$ probability.

DBE: Days before corn emergence, DAE: days after corn emergence.

obtained a competitive advantage over the agricultural crop, given that they were ready to absorb higher amounts of water and nutrients. Under moderate water deficiency, corn presents decreased photosynthesis because of a reduction in stomatal conductance, leading to stomatal closure and to transpiration reduction. Nevertheless, non-stomatal limitations (biochemistry) began to occur under severe and prolonged stress (Grzesiak et al., 2006). Although the water deficit has not been measured, there were visible symptoms of water deficit in corn plants that were cultivated in pots in which the forage emerged first, such as wilting and curling of the leaves. Under these conditions, the plants tended to close their stomata to minimize water loss to the environment. Stomatal closure reduces $\mathrm{CO}_{2}$ entry into the substomatal chamber, reducing the quantity of available substrate for the Calvin cycle. This hypothesis can be confirmed by evaluating the Ic/Ac ratio, which makes a direct association between the $\mathrm{CO}_{2}$ concentration in the substomatal chamber and the $\mathrm{CO}_{2}$ concentration in the environment, so the lower Ic/Ac value in the treatment presenting Brachiaria emergence $10 \mathrm{~d}$ before corn indicates that corn plants are consuming $\mathrm{CO}_{2}$ normally and that photosynthesis reduction is occurring because of the substrate reduction for photosynthesis.

These results demonstrate the importance of adequate crop seeding and fertilization in corn intercropped with Brachiaria, with the aim of achieving quick germination and development in the agricultural crop plants to the detriment of Brachiaria plants. In addition, the benefit of using sub-doses of atrazine and nicosulfuron herbicides in integrated cultivation systems is confirmed, because this regimen reduces the growth of Brachiaria plants and potentializes corn production.

\section{CONCLUSIONS}

Sub-doses of atrazine and nicosulfuron herbicides increased photosynthesis, stomatal conductance, transpiration, and water use efficiency rates in corn plants and reduced the same variables in Brachiaria plants. Brachiaria plants that emerged before corn presented higher photosynthesis, stomatal conductance, transpiration, and water use efficiency values and reduced these parameters in corn plants.

The higher nutrient availability increased the photosynthetic rate of the crop that first developed in the intercropped system.

\section{ACKNOWLEDGEMENTS}

The authors thank the Coordination for Improvement of Higher Personnel (CAPES) and the National Council for Scientific and Technological Development (CNPq) for their support and research grants.

\section{LITERATURE CITED}

Bianchi, C.A.M., J.I. Bergonci, H. Bergamaschi, G.A. Dalmago, B.M.M. Heckler, e F. Comiran. 2007. Condutância da folha em milho cultivado em plantio direto e convencional em diferentes disponibilidades hídricas. Ciência Rural 37:315-322.

Brodribb, T.J., and R.S. Hill. 2000. Increases in water potential gradient reduce xylem conductivity in whole plants. Evidence from a low-pressure conductivity method. Plant Physiology 123:1021-1028.

Brodribb, T.J., and N.M. Holbrook. 2003. Stomatal closure during leaf dehydration, correlation with other leaf physiological traits. Plant Physiology 132:2166-2173.

Cantarutti, R.B., N.F. Barros, H.E.P. Martinez, e R.F. Novais. 2007. Avaliação da fertilidade do solo e recomendação de fertilizantes. 1017 p. In Novais, R.F., V. Alvarez, N.F. Barros, et al. (eds.) Fertilidade do solo. Sociedade Brasileira de Ciência do Solo (SBCS), Viçosa, Minas Gerais, Brasil.

Cochard, H., L. Coll, J. Le Roux, and T. Ameglio. 2002. Unraveling the effects of plant hydraulics on stomatal closure during water stress in walnut. Plant Physiology 128:282-290.

Concenço, G., E.A. Ferreira, I. Aspiazu, A.F. Silva, L. Galon, F.A. Ferreira, et al. 2009. Uso da água por plantas de arroz em competição com biótipos de Echinochloa crusgalli resistente e suscetível ao herbicida quinclorac. Planta Daninha 27:249256.

Concenç, G., E.A. Ferreira, A.A. Silva, F.A. Ferreira, R.G. Viana, L. D'Antonino, et al. 2007. Uso da água em biótipos de azevém (Lolium multiflorum) em condição de competição. Planta Daninha 25:449-455.

Farquhar, G.D., and K. Raschke. 1978. On the resistance to transpiration of the sites os transpiration within the leaf. Plant Physiology 61:1000-1005.

Ferreira, L.R., D.S. Queiroz, A.F.L. Machado, e L.O. Fernandes. 2007. Formação de pastagens em sistemas de integração. Integração Lavoura-Pecuária. Revista Informe Agropecuário 240:52-62. Empresa de Pesquisa Agropecuária de Minas Gerais (EPAMIG), Belo Horizonte, Minas Gerais, Brasil.

Floss, E.L. 2008. Fisiologia das plantas cultivadas: o estudo do que está por trás do que se vê. 749 p. Universidade de Passo Fundo, Passo Fundo, Rio Grande do Sul, Brasil.

Freitas, F.C.L., M.V. Santos, A.F.L. Machado, L.R. Ferreira, M.A.M. Freitas, e M.G.O. Silva. 2008. Comportamento de cultivares de milho no consórcio com Brachiaria brizantha na presence e ausência de Foramsulfuron + Iodosulfuron-Methyl para o manejo da forrageira. Planta Daninha 26:215-221.

Galon, L., D. Agostinetto, P.V.D. Moraes, S.P. Tironi, e T. Dal Magro. 2007. Estimativa das perdas de produtividade de grãos em cultivares de arroz (Oryza sativa) pela interferência do capimarroz (Echinochloa spp.) Planta Daninha 25:697-707.

Grzesiak, M.T., S. Grzesiak, and A. Skoczowski. 2006. Changes of leaf water potential and gas exchange during and after drought in triticale and maize genotypes differing in drought tolerance. Photosynthetica 44:561-568. 
Lorenzi, H. 2000. Manual de identificação e controle de plantas daninhas. $5^{\text {a }}$ ed. 385 p. Instituto Plantarum de Estudos da Flora Ltda., Nova Odessa, São Paulo, Brasil.

Melo, P.T.B.S., L.O.B. Schuch, F.N. Assis, e G. Concenço. 2006. Comportamento de populações de arroz irrigado em função das proporções de plantas originadas de sementes de alta e baixa qualidade fisiológica. Revista Brasileira de Agrociência 12:37-43.

Ogliari, J., S.P. Freitas, A.C. Ramos, R.E. Bressan Smith, e A.R. Façanha. 2009. Sistemas primários de transporte de prótons integram os mecanismos de desintoxicação do mesotrione em plantas de milho. Planta Daninha 27:799-807.

Radosevich, S., J. Holt, and C. Ghersa. 1997. Physiological aspects of competition. p. 217-301. In Weed ecology: Implications for management. John Wiley, New York, USA.

Rigoli, R.P., D. Agostinetto, C.E Schaedler, T. Dal Magro, e S. Tironi. 2008. Habilidade competitiva relativa do trigo (Triticum aestivum) em convivência com azevém (Lolium multiflorum) ou nabo (Raphanus raphanistrum). Planta Daninha 26:93-100.
Sharkey, T.D., and K. Raschke. 1981. Effect of light quality on stomatal opening in leaves of Xanthium strumarium L. Plant Physiology 68:1170-1174

Shim, S.I., B.M. Lee, E.I. Ryu, and B.H. Kang. 2003. Response of leaf acetolactate synthase from different leaf positions and seedling ages to sulfonylurea herbicide. Pesticide Biochemistry and Physiology 75:39-46.

Silva, A.A., F.A. Ferreira, e L.R. Ferreira. 2007. Herbicidas: classificação e mecanismo de ação. p. 83-148. Tópicos em manejo de plantas daninhas. Editora UFV, Universidade Federal de Viçosa, Viçosa, Minas Gerais, Brasil.

Taiz, L., e E. Zeiger. 2009. Fisiologia vegetal. 4a ed. 848 p. Artmed, Porto Alegre, Rio Grande do Sul, Brasil.

Vidal, R.A., V. Spader, N.G. Fleck, e A. Merotto Jr. 2004. Nível de dano econômico de Brachiaria plantaginea na cultura de milho irrigado. Planta Daninha 22:63-69.

Wichert, R.A., and R.E. Talbert. 1993. Soybean (Glycine max L.) response to lactofen. Weed Science 41:23-27. 